\title{
Dos alienígenas à jurualogia: reflexões de um provável xamã guarani-mbya
}

From aliens to jurualogy: reflections of a potential Guarani-Mbya shaman

\author{
Bruno Huyer ${ }^{*}$ \\ *Universidade Federal de Santa Catarina - Florianópolis, SC, Brasil \\ Pesquisador associado ao Núcleo de Estudos sobre Saúde e Saberes Indígenas \\ brunonhuyer@gmail.com
}




\title{
Resumo
}

Considerando as reflexões de um jovem guarani que tem como possível destino tornar-se um karai (xamã), a aposta deste texto é etnográfica. Conduzidos por um amigo e interlocutor que acompanho por aproximadamente nove anos, somos levados a diversas especulações sobre o universo e seus habitantes. Aliando sua disposição mitopoiética através de verdadeiras exegeses filosóficas e sua busca por entender corporalmente quem são os brancos através do que chamou de jurualogia, Vera'i passou a demonstrar cada vez mais sua inclinação ao xamanismo mbya. Motivada por seus familiares desde sua infância, tal inclinação passa a efetuar-se na medida em que pessoas começam a procurá-lo em busca de cura e tratamento para suas doenças.

Palavras-chave: Guarani-Mbya; etnografia; xamanismo; mito.

\begin{abstract}
Considering the reflections of a young Guarani who has, as probable destiny, to become a shaman (karai), the bet of this text is ethnographic. Driven from him, a friend that I have been able to follow for about nine years, we are led to diverse speculations about the universe and its inhabitants. Combining a mythopoiesis disposition through philosophical exegeses, and willing to bodily understand whites with his jurualogy, Vera'i has increasingly revealed his propensity for Mbya shamanism, mainly motivated by his family members since his childhood, but corroborated when some came to seek him for healing and treatment for their illnesses.
\end{abstract}

Keywords: Guarani-Mbya; ethnography; shamanism; myth. 


\section{Verá Poty e os mundos possíveis ${ }^{1}$}

Mais uma vez, é noite. Afinal esta é uma etnografia que dependeu das madrugadas. Vera'i acabou de chegar de mais uma aula do Educação para Jovens e Adultos (EJA), e sentamos ao redor da mesa para conversar. Estamos na casa de seu cunhado que não estava, pois havia ido a reuniões junto aos órgãos indigenistas do Estado. Sua mulher e seus filhos estão na casa da xejaryi (avó). No aparelho de som, Vera'i pede para eu apresentar uma música nova a ele. Coloco um álbum de blues: "Vê se não lembra as músicas da opy [casa de reza]", sugiro. Vera'i escuta e começa a improvisar uma comunicação "profana" com nhanderu kuery (deuses) com o blues de Ali Farka Touré soando ao fundo. Para no meio para dizer:

Por que o mundo funciona desse jeito? Esse sistema que a gente conhece, que é o único sistema que faz o planeta girar? Esse sistema que toma conta, que toma conta de nosso psicológico, que nos invade. Por quê? Para que toda essa invenção? Deve haver alguma explicação! ${ }^{2}$

Estamos na Tekoa Ka'aguy Poty, uma aldeia guarani-mbya espremida entre plantações de soja e usinas hidrelétricas, mas encravada em um morro exuberante do rio Jacuí, no atual estado do Rio Grande do Sul, Brasil. Parte da vastamente documentada ocupação guarani através do Jacuí - caminho que leva os Guarani do centro do mundo yvy mbyte (hoje Paraguai), ao litoral (hoje Brasil) - e depois de tantos séculos de colonização não indígena na região, Ka'aguy Poty é uma das pequenas ilhas do arquipélago que hoje se tornou o território guarani-mbya no sul do Brasil.

Neste último entardecer a aldeia estava silenciosa, não fosse pelas máquinas colheitadeiras de soja que iriam nos acompanhar por toda a noite. Como havia previsão de chuva para os próximos dias, os agricultores optaram

1 Este texto é uma versão editada e adaptada do segundo capítulo de minha dissertação de mestrado (Huyer, 2017), defendida em abril de 2017 no curso de pós-graduação em Antropologia Social da Universidade Federal de Santa Catarina.

2 Essas e outras conversas presentes neste artigo foram todas gravadas durante minha estadia na Tekoa Ka'aguy Poty em abril de 2016. 
por estender o trabalho pela madrugada para não perderem a colheita. Às vezes pode-se ver a luz dos faróis das máquinas pelas frestas da casa - elas chegam bem perto de onde estamos. Mesmo assim, conversamos tranquilos, pois Vera'i sabe que a condição degradante dos seres humanos de hoje é decorrente dos problemas incontornáveis do teko axy: "Por que a gente não evolui através de nosso espírito? Tentar evoluir espiritualmente, cada um. Assim vai ser mais fácil. O problema é que isso de alguma forma foi bloqueado."

De alguma forma. Pois, antes de tudo, Vera'i reforça sempre a confusão característica do teko axy - um certo contexto que faz do conhecimento algo sempre relativo, extremamente permeado por enganos. ${ }^{3}$ Por outro lado, mesmo que a condição humana seja a de viver nessa confusão de uma terra onde tudo estraga, pode-se "evoluir espiritualmente", pois os eventos enganosos do mundo terrestre são também decorrentes dos mundos celestes, onde a verdade é "uma dama conhecida". ${ }^{4}$ Assim, enquanto consequências, ou imagens, de planos superiores, os eventos ocorridos nesta terra imperfeita podem ser interpretados como "restos" da verdade oriundos de planos celestes - sendo assim atravessada pelas variáveis tortuosas do teko axy. ${ }^{5}$

3 Tal expressão carrega variados significados. Teko axy: "vida imperfecta, dolorosa, naturaleza imperfecta", relacionada à enfermidade: "mba'e axy" (Cadogan, 1992, p. 112, 179). Entre os Guarani-Mbya com quem convivi, esta terra é imperfeita, nela há confusão e falta de entendimento provindo das divindades. Por isso, as coisas perecem, ao contrário do que ocorre nos planos celestiais onde moram os deuses em que nada estraga ou morre. Robert Dooley (1998, p. xxxi) traduz -eko axy por doença, sofrimento. Teko axy seria, a partir disso, o local em que esse sofrimento é vivido/experienciado, refere-se a esta terra onde tudo perece, estraga, ou se corrompe (marã), inclusive nossos corpos. Ver tratamento dado por Guilherme Heurich (2011) sobre o complexo relacional a que os Mbya acabam entrando no teko axy, e em Pierri (2013), a série de dualismos em perpetuo desequilíbrio presente na mitologia guarani-mbya que envolve a diferença entre teko axy e teko porã. No decorrer deste trabalho, espero que tal noção se torne cada vez mais apreensível ao leitor.

4 Nietzsche $(2005$, p. 7) falando sobre a verdade: "Supondo que a verdade seja uma mulher - não seria bem fundada a suspeita de que todos os filósofos, na medida em que foram dogmáticos, entenderam pouco de mulheres? De que a terrível seriedade, a desajeitada insistência com que até agora se aproximaram da verdade, foram meios inábeis e impróprios para conquistar uma dama?"

5 Aqui caberia uma longa nota, baseada na análise de Pierri (2013) sobre o "platonismo em desequilíbrio perpétuo". Resumindo, seguindo o autor, os Guarani seriam adeptos de uma espécie de "teoria da reminiscência" na qual as coisas da terra, teko axy, são nada mais que imagens de modelos em estado imperecível, localizados nas plataformas celestes. Dessa forma, a reminiscência é também a abertura para a superação da condição de teko axy e ascensão às plataformas celestes a ser superada pelos corpos. 
É com essa dificuldade de saída, ao mesmo tempo com uma abertura fragmentada da verdade (celeste), que Vera'i investiga os sinais que percebe à sua volta:

Os deuses e os espaços são muito grandes. Talvez cada Via Láctea pode ser um nhanderu [divindade]. E isso é só nossa imaginação, porque a gente vê desse jeito: todo esse mundo, essas estrelas. Imagina o que seria para uma formiguinha, tem que pensar que a gente é quase inexistente. Imagina que a gente solta um pozinho em cima das formiguinhas, o que elas veriam? O que sentiriam? Elas devem ficar tentando entender, sem saber nunca o que é.

O ponto de vista das formigas parece ser uma preocupação antiga de Vera'i. Pelo menos era o que me diziam quando o conheci em 2009, na aldeia guarani em que morava na época, localizada no município de Salto do Jacuí (RS). Nem um par de anos fazia que seus familiares haviam chegado por aquela região motivados em descobrir a boa distância, ou a única distância possível, para desenvolver com Bonifácio, o pai, desde que ele os deixara para viver com sua nova esposa xenhora (não indígena). A amizade com Vera’i foi rápida. Fomos caminhar pela aldeia, ele fumava seu palheiro, eu observava seu jeito simpático e sua abertura com pessoas tão estranhas como eu naquele momento. É comum ouvir relatos, sobre os Guarani-Mbya, de que são todos muito fechados, tímidos, e que as visitas precisam ser muito respeitosas para não atrapalhar seu cotidiano de paz e contemplação religiosa. Ali, em poucos minutos, Vera'i deslocou todas essas pressuposições. Estávamos já caminhando pela aldeia, visitando as enormes quedas d'agua do rio Jacuí, e conversando sobre os problemas do mundo.

Foi nessa época que seus familiares comentaram que umas das coisas mais curiosas de sua infância era de que ele podia observar durante horas o comportamento das formigas: conseguia ficar o dia inteiro as acompanhando sem que nada o distraísse. Como sempre ressaltavam, essa capacidade de concentração e paciência corroborava a previsão feita por seu avô quando descobriu o nome de Vera'i - Verá Poty - na ocasião do nhemongarai. ${ }^{6}$ Seu avô e karai (forma

6 Importante ritual realizado na opy (casa cerimonial) na época da colheita do milho, ara pyau. São inúmeras as digressões sobre o nhemongarai; para a primeira descrita na etnologia, ver Curt Nimuendajú (1987, p. 29). Nesse ritual ocorre o "batismo" de todas as sementes $\rightarrow$ 
mais comum para se designar o xamã mbya), Dionísio Duarte, comentou no momento em que recebia dos deuses o nome de seu neto que eles também haviam sussurrado a possibilidade de seu neto futuramente tornar-se karai. Tal previsão parecia gerar certa ansiedade entre seus parentes a respeito do destino de Vera'i, já que estavam sempre a espera da concretização de uma liderança xamânica entre eles. Quando Vera'i voltava de bailes, por exemplo, gostavam de brincar com a suposta decepção de que seu destino deveria ser tomar gosto pelos saberes divinos, e não o gosto por bailes e bebedeiras. Mas Vera'i achava graça dessas coisas, e não parecia nunca premeditar suas ações e desejos na busca por tornar-se aquilo que seu avô previra, ou que seus familiares ambicionavam. Mesmo assim, não deixava de interessar-se pelos saberes e conhecimentos divinos.

A busca por um conhecer inspirado pelos deuses, inclusive, foi motivada por seu avô, que o incentivava a pensar com muita concentração e meditação (-japyxaka) sem a necessidade de buscar a mediação dos karai para acessar as ciências divinas. Era assim que em Ka'aguy Poty, Vera'i respirava fundo, fechava os olhos, e tentava responder minhas perguntas com respostas guiadas - "xenhe'ẽ ru ete kuery, xenhe'exy ete kuery omoexakã nhande apyte py",? explicou-me ao colocar a mão no cume de minha cabeça. Traduzia apyte por "janela psicocinética", aquilo que Cadogan (1992, p. 30) definiu como "la coronilla que la sabiduría divina penetra en el alma humana". Era por tal "janela psicocinética" que Vera'i abria-se ao conhecimento divino, tentando fazer com que o "reflexo luminoso" ${ }^{8}$ vindo dos deuses amplificasse seu entendimento sobre o mundo.

$\rightarrow$ e o descobrimento pelos karai (xamãs) dos nomes das crianças, ou, mais especificamente, do lugar de onde as nhe'ẽ vieram. Se as nhe'ẽ vieram de Tupã Ru Ete (divindade das chuvas e raios), são alguns nomes que se pode dar aos pequenos guarani, como por exemplo o nome de Verá aos meninos e de Pará às meninas; se vieram de Nhamandu Ru Ete (divindade do Sol) são outros, como, por exemplo, Kuaray para meninos e Jachuka para meninas. Para uma relação completa dos nomes de acordo com as divindades que os enviam e de acordo com os Mbya com os quais mais convivi, ver Mariana Soares (2012).

7 Em uma tradução baseada em Robert Dooley (1998), teríamos algo como: "Os pais de nossas almas-palavras, as mães de nossas almas-palavras clareiam o cume de nossa cabeça." Tal fala, especificamente, foi dita a mim em conversa gravada no dia 03/04/2016.

8 Outra tradução sua para -exakã. 
Ao mesmo tempo, reconhecendo a impossibilidade de um conhecimento profundo pela condição teko axy na qual estamos mergulhados, Vera'i ressaltava que o conhecimento e o saber divino acabam sendo sempre metafóricos no seu caminho até a terra. Aqui, metáfora, seguindo os termos de Vera'i, parece ser uma dobra que confunde, uma refração da luz que vem dos deuses. Nesse sentido, teko axy parece ser uma metáfora de teko porã (o plano imperecível dos deuses). Ironicamente, se a etnologia vem cada vez mais se afastando da metáfora como operação de entendimento para equivocações controladas entre ontologias (Viveiros de Castro, 2004), já que ela pode produzir efeitos culturalistas em nossas análises (p. ex. a mandioca é como uma menina ${ }^{9}$ ), Vera'i, entretanto, advoga a metáfora como a melhor maneira para pensarmos a relação entre humanos e deuses, entre os planos celestes (teko porã) e terrestre (teko axy)..10

Pois o que Vera'i parecia ressaltar é que entender os deuses a partir de um entendimento literal de suas falas gera grande confusão, na medida em que não leva em consideração que estamos imersos no teko axy. Dessa forma, até mesmo o falar dos deuses vem refratado pelo teko axy, e por isso acaba sendo uma verdade de alguma maneira relativa.

A condição possível de relação com as divindades parece ser, portanto, metafórica. Elas falam verdades, nós só podemos entender metaforicamente. Parece ser a única percepção possível daqueles em teko axy ou daqueles que buscam o conhecimento dos nhanderu - como se tal conhecimento sempre

9 Uso tal exemplo, pois os Mbya contam que "muito tempo atrás existia um casal que tinha uma menina muito feia e muito magrinha, por isso as outras crianças não gostavam de brincar com ela, então a menina ficava muito triste. Um dia ela fugiu ao mato e naquele dia veio uma chuva forte e veio um raio nela. Depois a mãe a procurou e não a encontrou. Naquela noite a mãe sonhou com uma voz que lhe falava para ir novamente ao mato e enterrar a filha dela. A mãe foi, a encontrou, enterrou e voltou para casa. Depois de alguns dias, a mãe voltou onde estava enterrada a filha e viu que tinha um pé [planta] nascendo. A mãe viu a planta nascendo e ficou muito assustada, porque não a conhecia. Depois ela sonhou de novo, naquela noite, com uma voz que falava que era a filha que tava brotando, e daí lhe falou o nome que era mandioca que iria alimentar toda a aldeia para sempre, e que tinha que guardar a rama para sempre tê-la." (Ará, em entrevista a Soares, 2012, p. 87).

10 Valeria a pena aprofundar o rendimento de pensar a relação entre teko porã e teko axy usando a chave de leitura de Vera'i. A metáfora parece operar de uma maneira interessante nessa relação, já que muitos especialistas já exploraram a noção de imagem terrestre de modelos celestes ao pensar a diferença entre os milhos que aqui precisam ser plantados, cuidados, ao contrário daqueles dos planos celestes que crescem sozinhos. Ou seja, o que Vera'i parece estar sugerindo é a ideia de que a cópia terrestre seria uma metáfora oriunda dos modelos dos planos celestes. 
viesse atravessado por um efeito desviante, por uma refração da luz em seu caminho até a terra. E desse desvio luminoso e metafórico produz-se muito desentendimento. Nesse sentido, o bom karai é aquele que entende tal refração metafórica da verdade e, ao mesmo tempo em que usa da metáfora para falar com aqueles que não são inspirados pelos deuses, também a desmonta na tentativa de chegar próximo às verdades divinas.

Assim passávamos as noites, conjecturando sobre as verdades dos deuses e seu caminho "tortuoso" ao chegar na terra. Desde sua infância, quando observava as formigas e tentava entendê-las, até os dias de hoje quando se propõe a um exercício constante de tradução de seu mundo às palavras e referências não indígenas, Vera'i tornava-se cada vez mais o karai que seu avô, junto às divindades, havia previsto. Principalmente, ao compor inúmeras teorias sobre o universo e suas criações - produzindo aquilo que Joanna Overing (1990) sugeriu ser a ação prototípica dos xamãs na Amazônia, a de "criador de mundos", como veremos mais adiante.

Se desenvolvia de forma bastante espontânea sua curiosidade sobre os saberes dos deuses, as práticas curativas eram motivadas por seus familiares, que 0 convocavam para aplicar fumaça de tabaco (-moataxī) quando sentiam-se enfermos. No início, tudo parecia baseado em performances burlescas, mas com o passar do tempo a concentração tornou-se regra. Assim mesmo, Vera'i ressaltava que não tinha o conhecimento necessário para um tratamento realmente eficaz. Pois, se conseguia aspirar as enfermidades que sugava dos doentes, comentava que não conseguia tirá-las por completo; cuspi-las para fora de seu próprio corpo e do corpo enfermo - dizendo que a enfermidade ainda restava um pouco nele. De fato, uma das características mais marcantes de Verá é seu estado quase constante de enfermidade, um estado que o faz estar sempre sob olhares de sua família, já que passa de uma doença a outra, raramente estando completamente são.

É nesse estado de quase-enfermidade constante, acompanhado por um palheiro, e sempre disposto à ciência divina, que Vera'i passou a ter certo reconhecimento por suas habilidades xamânicas. Tais habilidades se tornaram evidentes quando um respeitado karai da aldeia de Tamanduá, na Argentina, ficou doente e pediu que Vera'i fosse tratá-lo. Depois de algumas horas massageando e aplicando fumaça no corpo do karai, disse-me que não havia conseguido tirar por completo a patogenia do corpo. No dia seguinte, contudo, tal senhor melhorou bastante e, dando-lhe muitos elogios, pediu que voltasse mais vezes. 
Mas Vera'i nunca mais voltou. Seguiu sua caminhada de aldeia em aldeia na busca de bailes e de alegria. Nesse sentido, a certeza de estarmos diante de um karai dependia das escolhas realizadas por Vera'i que viriam ou não efetuar suas predisposições xamânicas, apontadas pelos deuses através de seu avô desde o nhemongarai, e por sua família quando denunciavam suas habilidades desde a infância. A real efetuação de todas essas indicações, por conseguinte, mantém-se aberta e coletiva, já que Vera'i é por muitos considerado "doido", quando estes que o acusam não acompanham suas teorias peculiares sobre $o$ cosmos, nem sua consequente abertura em relação aos brancos. Como veremos, parecem ser justamente essas duas "características" interligadas que o colocam a um passo do xamanismo ameríndio em geral, e do mbya em particular.

\section{Dos alienígenas}

Uma das coisas que mais deixava Vera'i perplexo era a ignorância dos jurua (brancos) com respeito à imersão no teko axy - essa condição terrena e inevitável que faz a verdade refratar. Ignorantes que somos dessa condição, investimos em observações míopes a respeito do universo:

O que os cientistas tanto buscam com suas viagens espaciais? O que eles querem encontrar? Se está tudo aquil O universo é espiritual! Está tudo ligado. A gente já não seria nada sem eles [os deuses] - é simples assim. Por que algo tão simples pode ser tão complicado?

A única possibilidade de conhecimento total está na ascensão aos domínios celestes através do aguyje. Acessar a ciência divina nos faria capaz de colapsar espaço e tempo tais quais os conhecemos, na medida em que nada é impossível aos deuses. Por isso, qualquer avanço tecnológico parece superficial para Vera'i quando comparado às habilidades possibilitadas pela maturação corporal que escapa da morte (aguyje):

Vera'i: [Poderíamos ser aperfeiçoados] se conseguíssemos passar daqui para outra, para outra linha do tempo.

Bruno: Outro tempo? Eles [deuses] têm outro tempo? 
V: Eles não morrem mais, e a gente morre ainda! Imagina, cada ano eles envelhecem e podem voltar a ficar jovem quando quiser. Não morrem mais, não morrem mais! [...] [Lá] não tem tempo, só pra nós que existe tempo. Não é mais necessário tempo. Por isso que é incrível. E o incrível é que a gente está conectado a eles. Para gente, passa tudo rápido. Para eles, são ciclos e mais ciclos.

As características do aguyje são, segundo Vera'i, ignoradas pelos homens da ciência que acabam confundindo-se com sua exagerada empiria, levando-os a produzir um conhecimento superficial. É somente através do aguyje que as pessoas acessariam a potência e a verdade divina, tornando-se nhanderu mirĩ capazes de tudo.

Quando Joanna Overing (1990) se deparou com as inúmeras versões mitológicas explicitadas pelos xamãs piaroa demorou um tempo para compreender que não estavam baseadas nas lógicas do tempo e da sequencialidade, mas, sim, estariam baseadas em temas morais de determinados "personagens", versões que relacionavam conceitos entre elas mesmas, fazendo emergir outros efeitos que não as lógicas que buscava. A habilidade constante em fabricar mundos, ou versões deles, pelos xamãs piaroa, fez Overing buscar em Nelson Goodman o conceito de "criador de mundos" para dar conta desses "cosmólogos indígenas" (Overing, 1995). Vera'i, de maneira similar, produz explicações sobre o universo criando versões e recortes a partir de suas experiências e seus quadros de referência: “Se mundos são tanto criados como descobertos, então conhecer é tanto recriar como reportar... Compreensão e criação andam juntas" (Goodman, 1978, p. 22 apud Overing, 1990, p. 25, tradução minha).

Nesse sentido, Vera'i defende que não podemos analisar ou conhecer o mundo divino com métodos terrenos e humanos. Se entendermos literalmente as verdades que chegam das divindades, provavelmente estaremos com uma perspectiva humana a respeito de um mundo não humano, mas celeste e divino. Esse seria o grande equívoco dos jurua (e de alguns karai).

A única maneira radical de burlar a refração da verdade em seu caminho até o plano terrestre é através do aguyje - a maturação corporal que ascende a pessoa mbya aos planos celestes. Para quem ascende a tais planos celestes, 0 entendimento sobre o universo e suas possibilidades de vida é expandido. O tempo e o espaço são outros. Pode-se viajar no tempo, assim como através do espaço, tornando-o facilmente acessível a esses seres - por isso, buscar 
uma sequencialidade espacial, ou mesmo temporal em teorias genesíacas, não pode fazer qualquer sentido ao plano dos deuses, e tal empreendimento só pode levar, invariavelmente, à ignorância e à confusão naqueles que isso buscam.

A seguir, reproduzo uma ilustração que tenta dar conta dos movimentos dos nhanderu através do cosmos, os quais conseguem mover-se entre as plataformas celestes e terrestres sem qualquer restrição. Vera'i não deixava de ressaltar que aquilo que desenhava era uma reprodução de alguém que estava inserido no teko axy, tentando achar um sentido lógico que seria impossível a alguém imerso na confusão desta terra, onde pouca certeza pode existir. Mesmo assim, se propôs a desenhar a capacidade dos nhanderu kuery em estar em todos os lugares do universo, colapsando distâncias e tempos que a nós parecem tão grandes e infinitos.

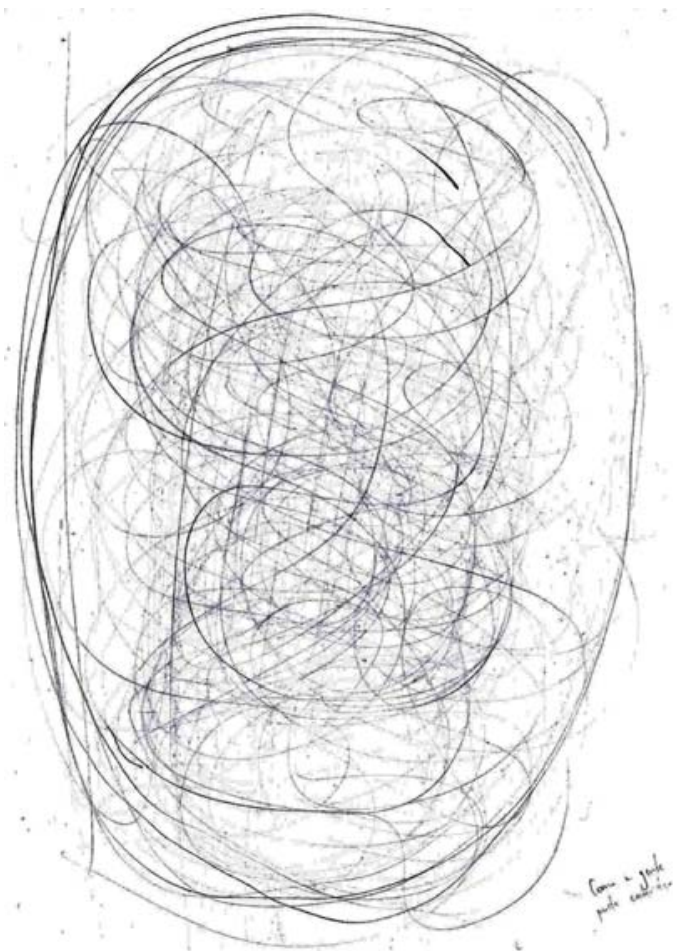

Figura 1. Capacidade dos nhanderu de transitar entre diversos espaços e tempos (desenho de Verá Poty, 2016). 
Dessa forma, qualquer julgamento terrestre é certamente apressado, pois pode ser facilmente torcido pelas possibilidades abertas nos planos celestes possibilidades que nossa imaginação sequer alcança. Por isso, para Vera'i, um dos grandes equívocos causados pela ânsia de conhecer dos jurua (poderíamos dizer que seria um conhecer míope, já que não considera os conhecimentos divinos) está na confusão que os brancos fazem quando identificam alienígenas ou óvnis ${ }^{11}$ perambulando pelos céus. Para Vera'i, isso é uma caricatura do conhecer científico, cego às possibilidades dos planos celestes. Na verdade, tais objetos e seres são justamente aparições daqueles que conseguiram alcançar a maturidade corporal, a sublimação em deus (aguyje) e que, portanto, conseguem viajar através do espaço com facilidade. É nessa condição divina que conseguem aparecer e desaparecer em instantes, sempre enquanto luzes ofuscantes - nada mais característico do reflexo luminoso das divindades. Enfim, os alienígenas são, na verdade, "pequenos" deuses: nhanderu mirñ.12

Porém, isso não é tudo. Se os brancos se confundem com as aparições dos nhanderu mirĩ, não se pode descartar a existência de extraterrestres. Antes de desconsiderar completamente as hipóteses científicas sobre vida extraterrestre, Vera'i, inscreve o cosmos de maneira radical no regime da multiplicidade, o que o faz conjecturar: podem existir outras plataformas terrestres com a existência de outras vidas humanas. Ou seja, podem ser muitos os yvy reko axy (terra imperfeita, corrompida, doente), e, desses outros planos, pode ser que haja seres (extraterrestres) que também alcançam o aguyje e, assim, viajam através do espaço na condição de nhanderu mirĩ:

B: Uma vez tu falou, não sei se entendi direito, que os nhanderu mirĩ foram seres elevados de outros planetas, não necessariamente daqui. Porque teriam os nhanderu mirĩ daqui, mas que poderiam ter nhanderu mirĩ elevados de seres viventes em outros planetas.

11 Objetos voadores não identificados.

12 Vale ressaltar que os nhanderu mirĩ são bem mais complexos do que poderia sugerir uma tradução como "pequenos deuses". Seu uso aqui é uma tentativa de dar sentido até mesmo em uma tradução literal dos termos seguindo a narrativa de Vera'i. Espero que ao longo do trabalho fique mais clara a complexidade desses seres divinos que já foram pessoas. 
V: Eu acho que tem essa possibilidade. Porque não somos únicos. Imagina, acho que não dá para dizer que somos únicos. Porque são átomos, átomos e átomos. É tudo átomos, átomos e átomos. O universo é um átomo. Tudo pertence a só uma coisa. É que não dá para imaginar bem porque esse universo é infinito, não dá pra imaginar, é infinito. Pensa que são tipo bolhas: átomos, átomos e mais átomos. Muitas bolhas, e bolhas. Tudo parece ligado. Então não somos únicos, disso eu quase tenho certeza. Quase. Que não somos só nós, que existem vários “Sol”. Talvez “Sol” maior que o nosso. B: Tá, mas e os outros “Sol” também são Nhamandu, ou são outros?

V: São Nhamandu. Eu acho que disso não podemos passar, só eles. Eu disse também que a gente é igual a eles, só que a gente tá nessa fase e eles tão naquela. Num nível muito, muito alto, sabe? Bah, cara. É que eu não consigo imaginar depois do Nhamandu Ru Ete. Dele não tenho como dizer. Ele é muito, muito. Acho que tem uma teoria, não sei se teoria, mas tem uma dizendo que o deus supremo é ele, todas essas bolhas, átomos, seriam dentro dele. Ele criou nós dentro dele. Ele é tipo uma fumaça onde contém esses elementos. Ele abriu uma lacuna dentro dele, um espaço para tudo. Para nós.

A cosmogonia de Vera'i segue a lógica da multiplicidade: ela está inscrita nos corpos, nos espíritos, na possibilidade de vida extraterrestre, assim como na diversidade nesta terra. Como salientou em outra ocasião: “Esses já são seres muito grandes, é nhanderu! É tipo átomo, sabe, é que dentro de nós existe um universo também. É só a gente que pensa que a gente é sozinho. É que a gente pensa que é um ser central, mas existe um monte de universo dentro de você também, imagina."13

Daniel Pierri (2013, p. 32) já ressaltou o fato de que o cosmos guarani seria "inscrito no regime da multiplicidade, recortado por uma miríade de populações celestes". As falas de Vera'i apontam para tal ponto de vista, proliferando multiplicidades e coletivos que não parecem tender ao Uno, senão o Uno enquanto modalidade do Múltiplo, característica já destacada por outros autores (Macedo; Sztutman, 2014).

Tal multiplicidade e a possibilidade de vida extraterrestre levou Vera'i a produzir um desenho a respeito da qualidade atômica do universo, eu diria

13 Vera'i usava muito deste imperativo em nossas conversas. De certa forma, o recurso malinowskiano ("Imagine...") não é restrito a nós, ocidentais, quando o objetivo é provocar um certo efeito literário e envolvente naqueles que nos leem ou escutam. 
infinitesimal, ${ }_{14}^{14}$ no qual Nhanderu engloba todos os planos, sem a existência de uma plataforma terrestre única centralizada. Como veremos, tal "versão" de mundo, para usar os termos de Goodman citado por Overing (1990), não está necessariamente em consonância absoluta com outras "versões" produzidas por Vera'i em outros momentos, ou com "versões" produzidas por outros Guarani - mas está perfeitamente em consonância com a característica dos xamãs enquanto "criadores de mundos" (Overing, 1990), a partir da qual produzem/ explicam mundos que correspondem às experiências deles em sua relação com os deuses e, também, daqueles que os escutam.

A seguir reproduzo tal ilustração que tende a dar conta do aspecto miriateísta do cosmos mbya (Macedo; Sztutman, 2014; Tarde, 2007). Esta segunda ilustração, também produzida por Vera'i, foi desenhada justamente quando ele explicava que o universo eram "átomos, átomos e mais átomos", ou "bolhas e mais bolhas", uma dentro da outra.

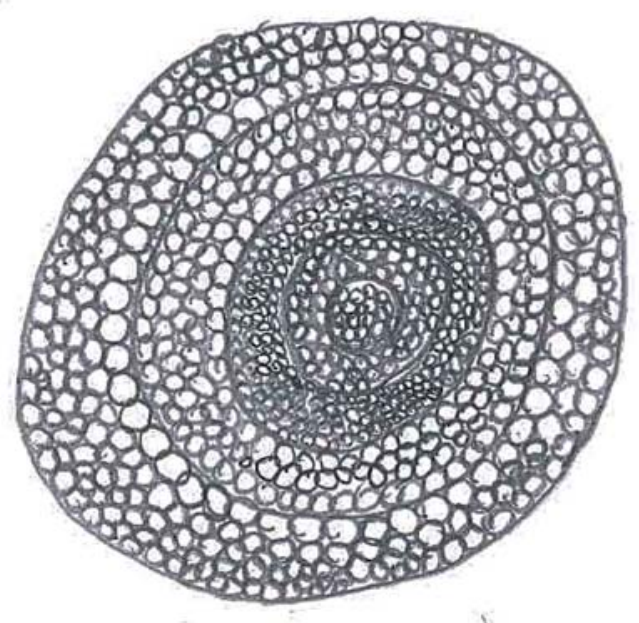

Figura 2. O cosmos com sua característica atomística e infinitesimal (desenho de Verá Poty, 2016).

14 Verá Poty, ao falar da característica atomística do universo e dos planos celestes, lembra Gabriel Tarde (2007, p. 78) sobre o sistema monadológico: “Todo fenômeno não é senão uma nebulosa decomponível em ações emanadas de uma infinidade de agentes que são outros tantos pequenos deuses invisíveis e inumeráveis." 
O importante a ressaltar é a disposição de Vera'i em analisar o universo por dedução dos mais diversos eventos que consegue observar e pesquisar, vistos enquanto indícios dos ensinamentos mais gerais de seu avô e dos deuses que escuta quando em meditação (-japyxaka). Dessa maneira, a vida extraterrestre está em consonância com a multiplicidade característica do cosmos, expressa enquanto virtualidade e potencialidade de um sistema de "dualismo em perpétuo desequilíbrio"15 (Lévi-Strauss, 1993), que em última instância é um sistema aberto à diferença. Considerando os extraterrestres, Vera'i parece pontuar a proliferação de diferença nos planos terrestres, ao mesmo tempo em que segue sua multiplicação a partir da ascensão aos planos celestes. Características das mitológicas ameríndias, a virtualidade presente do Múltiplo no Uno também se desdobra na cosmogonia pensada por Vera'i. Antes de perceber uma terra única, faz o "platonismo em perpétuo desequilíbrio" (Pierri, 2013) guarani-mbya ${ }^{16}$ se desdobrar em várias terras possíveis, onde a existência dos seres terrestres guarda em si a possibilidade da existência de extraterrestres, fazendo-nos lembrar da célebre passagem de Lévi-Strauss em História de lince, quando se permite afirmar que o pensamento ameríndio pôde prever a existência de não índios, já que sua “ideologia bipartida”, em deslizamento contínuo, fez com que "a criação dos índios pelo demiurgo tornasse automaticamente necessário que ele tivesse criado também os não-índios" (Lévi-Strauss, 1993, p. 200).

15 Tal dualismo aparece naquilo que acabou sendo o último volume da monumental Mitológicas, História de lince (Lévi-Strauss, 1993). Ali, Lévi-Strauss se propõe a compreender a facilidade com que os brancos passaram a ser incorporados nos diversos mitos ameríndios já em pouco tempo de contato. Pela existência de uma "ideologia bipartida" aberta, ou um dualismo que, antes de assentar-se enquanto bloco de oposições estanques e estáveis, preserva em seu interior dicotômico certa instabilidade, tal "ideologia" transpõe sistemas antes binários, em séries contínuas de oposição, de tal forma que está sempre "aberto ao outro" - uma abertura ao evento a ser sempre incluído nos modelos nativos, pois estes preservam em si uma certa virtualidade do evento, do porvir.

16 Na fina exposição de Pierri (2013), vemos como o par mitológico Kuaray e Jaxy servem como modelos de conduta aos Mbya na terra, de tal forma que além deles indicarem o "dualismo em perpétuo desequilíbrio" sugerido por Lévi-Strauss, eles acabam instituindo um certo "platonismo" nas lógicas de pensamento guarani-mbya. Isso porque Jaxy é um irmão (gêmeo lógico) que passa tentando imitar Kuaray, fazendo Pierri (2013, p. 47) perguntar-se: "O que são gêmeos desiguais senão uma imitação/transformação um do outro?" Nesse sentido, a gemelaridade entre os Mbya não estaria somente em desequilíbrio, mas pautada por um tipo de imitação transformativa, um deslizamento diferenciante, um certo motor incansável de um sistema dinâmico baseado, principalmente, em noções de transformação corporal que tendem a instituir Kuaray e Jaxy como modelos de conduta aos humanos, por isso o "platonismo" de tal sistema. 
Passemos, então, a suas elucubrações a respeito dos brancos (jurua). Questionando-se sobre esta terra, Vera'i consegue explorar ainda mais as "fronteiras" do pensamento guarani-mbya a respeito das diferenças entre índios e brancos, tensionando os limites e abrindo-se à criatividade. ${ }^{17}$ Nesse momento, o contágio aparece como método de pesquisa privilegiado para inquirir a respeito dos jurua.

\section{Ajurualogia}

Foi em Porto Alegre que Vera'i revelou-me seu projeto específico com relação aos brancos: a jurualogia. Tal estudo a respeito dos jurua teria como método a própria etnografia. Mas, com o intuito de radicalizá-la, dizia querer não somente ouvir e entender as falas dos jurua, mas gostaria de voluntariamente jepotar-se (metamorfose guarani) em branco para entender "o ponto de vista dos jurua sobre o mundo" (vale ressaltar que não são palavras minhas). Depois de tal pesquisa, dizia que adoraria escrever um livro comigo sobre o assunto. Segundo ele mesmo, a metamorfose guarani, o -jepota, significaria isso: entregar-se ao ponto de vista do outro.

A jurualogia já havia começado há alguns meses antes de ele conceituá-la. Quando ia para Porto Alegre, dizia, não sem jocosidade, que estava realizando seu "trabalho de campo", ou sua "observação participante"..$^{18}$ Inúmeras vezes passava dias na casa de estudante da Universidade Federal do Rio Grande do Sul (UFRGS), onde a curiosidade pelos brancos era sanada por ter à disposição um verdadeiro laboratório das variações jurua nesta terra. Na Casa

17 Penso aqui na criatividade em termos de Wagner (2010), em que está intimamente conectada, em termos de uma dialética, com as convenções de determinado grupo/estrato/sociedade. Conforme Wagner (2010, p. 76), "toda experiência e todo entendimento é uma espécie de invenção, e a invenção requer uma base de comunicação em convenções compartilhadas para que faça sentido". Desse modo estabelece-se a dialética entre invenção e convenção presente em toda experiência. Tal dialética opera indefinidamente em termos de uma obviação ("prevê e descarta") de um termo sob outro nos processos semióticos e práticos. Nesse sentido, procuro ressaltar a capacidade inventiva de Vera'i, sempre a partir de "convenções compartilhadas".

18 A título de comentário, Vera'i certamente aprendeu tal vocabulário com este autor que vos fala, assim como com outros estudantes de antropologia com quem conviveu. Contudo, como sua capacidade "criativa" é incansável, tal vocabulário já é de seu uso e transformação próprios, como atesta o termo jurualogia. 
do Estudante Universitário (CEU), se travestia com roupas femininas e inquiria sobre a homossexualidade junto aos moradores, querendo entender sobre as discussões de gênero presentes naquela casa: "Não é que todo mundo vai virar [homossexual], mas as pessoas estão todas experimentando, se entendendo, porque somos todos teko axy, independente de nossas diferenças aqui nessa terra." Além disso, passava tentando aprender mais sobre as músicas que ali eram tocadas. Quando eu perguntava sobre suas experiências, Vera'i dizia que estava aprendendo muito sobre sua própria espiritualidade e também sobre a organização política dos brancos.

Sua jurualogia também se valia de outro método, que em muitos causava espanto: o sexual - já que era experimentado, justamente, com as xenhora (mulheres não indígenas). Revelou-me que para entender sobre os brancos de verdade, com toda sua potência, sabia que precisaria se deixar levar em todos os sentidos, mesmo sabendo dos riscos alertados constantemente pelos karai com todas as histórias e conselhos de que os Mbya não deveriam se misturar com os jurua/xenhora. Mas Vera'i, assumindo os riscos, queria ir até onde achasse suficiente para seus objetivos relacionais e um tanto "semióticos". Garantia a mim que possuía as condições de controlar os limites e os perigos envolvidos nas relações por demais próximas com os brancos. Vera'i não negava o desafio, mas também não aceitava os limites impostos pelos karai. Alegava que a relação por demais próxima com os brancos é um processo bastante perigoso para aqueles que não a dominam, mas que ele saberia controlar as ameaças envolvidas. Se sentia consciente o suficiente para envolver-se e compreender radicalmente como são os jurua sem perder o que chama de "espiritualidade mbya". E mais, defendia que a partir de tal relação, alcançaria entendimentos mais amplos sobre o mundo e o universo das divindades.

Suas experiências sexuais com as xenhora foram adiante. Depois de alguns meses, quando cheguei novamente na Tekoa Ka'aguy Poty para vê-lo, ele estava bastante debilitado. Caía uma forte tempestade, e Vera'i com seu filho no colo mostrava-lhe as nuvens de chuva chegando com o forte vento que passava. Dizia para o filho observar a caminhada dos Tupã na terra e comentava comigo de que por ser Verá não sentia medo das tempestades, dessas caminhadas dos deuses que fazem o chão tremer e que um dia podem varrer da terra as imperfeições do teko axy. Mas se não era pela tempestade que Vera'i estava debilitado, era por causa do término de um de seus relacionamentos virtuais. 
Nesse mesmo dia, ele havia decidido terminar seu relacionamento que mantinha através do Facebook com uma não indígena (xenhora). O que era para ser um término tranquilo, já que tampouco se conheciam (a não ser pela internet), tornou-se um rompimento violento, com a menina dizendo-lhe coisas pesadas cheias de palavras de ódio. A menina, furiosa, chamava-lhe de mentiroso, pois ele havia prometido ir a seu encontro em sua cidade, a vários quilômetros dali. Por essa discussão, Verá ficou bastante debilitado e doente, especificamente pela força das palavras da xenhora, agora ex-namorada.

Mas Vera'i também já estava decidido. Tinha resolvido terminar o [princípio de] relacionamento com ela, pois já estava apaixonado por outra - outra também xenhora, e que também conheceu através do Facebook. Esta menina era de São Paulo, e ele manteria o relacionamento virtual com ela por bastante tempo, resolvendo terminar somente quando seu irmão mais velho, Kuaray Poty, junto com seu sobrinho, Karai Tataendy, ficaram insistindo para Verá terminar a relação, já que ele não deveria relacionar-se com alguém que nem conhecia pessoalmente, e mais, alguém cujo pai era policial militar, como iríamos descobrir depois. Pois o fato de o sogro ser policial, com fotos no Facebook portando armas, tornou-se determinante para o fim da relação. Nada que durasse muito tempo, pois meses depois ainda conversavam pelo celular. Além dessa menina de São Paulo, Vera'i mantinha relacionamentos com outras xenhora em mais de uma cidade do país. Entre as Mbya, possuía outro par de relações ativas.

A abertura aos brancos, principalmente às relações sexuais, assim como a estadias prolongadas nas cidades, eram citadas como parte de seu projeto a respeito da jurualogia - essa ciência da relação sobre/com os jurua. A disposição de Vera'i para tal projeto, que de fato ocorria não sem uma certa jocosidade, possuía relações coerentes com suas percepções/teorias sobre as origens dos brancos. Nesse sentido, sua disposição de compor explicações sobre o universo e sobre a origem das diferenças entre os povos, parece dialogar, de uma maneira bastante original, com o que Peter Gow (2001) chamou de mitopoiesis: o processo pelo qual, através do envelhecimento dos narradores, os mitos vão adquirindo suas nuances e sendo transformados pelos eventos ocorridos em suas vidas, num processo dialógico de informar e ser informado pelo presente, assim como pelo interesse daqueles que escutam. Com efeito, mesmo que jovem, Vera'i se prestava a pensar o presente e suas experiências através e com os mitos, e assim imprimia suas interpretações e transformações, 
possivelmente, conjecturo, por essa disposição em tornar-se karai destacada por seus familiares.

Nas elucubrações de Vera'i sobre as populações celestes e terrestres, os mitos não funcionam como se fossem um estável thesaurus do conhecimento, onde ele simplesmente resolveria todos seus questionamentos. Ao invés disso, Vera'i não deixa de mostrar que os discursos míticos não se prestam a verdades absolutas, à la ideogramas (Calavia Sáez, 2008), por estarmos sempre em uma condição teko axy, onde o conhecimento verdadeiro é bastante relativo e incerto.

B: Tu falava que somos todos filhos de Nhanderu, todo mundo aqui na terra sendo irmão. Tu colocaria os jurua como irmãos também? Ou de repente cunhados? [risos]

V: Espiritualmente?

B: É, não sei.

V: Todos somos irmãos.

B: Mas ao mesmo tempo tem diferenças.

V: Tem diferenças, mas elas só acontecem aqui, sabe.

B: Mas porque tu acha que os jurua desenvolveram essa espiritualidade diferente?

V: Cara, isso começou há muitos anos atrás. Começou há muitos anos atrás. Eles optaram demais pelas coisas terrenais.

B: Foi uma escolha?

V: Foi uma escolha mesmo, aí todas as gerações vindas desse grupo vieram crescendo dessa maneira. É por isso que é importante, para gente, se comportar bem, para que nossos filhos saiam parecidos conosco. Imagina, se acontece há milhares de anos isso, como que seus filhos vão continuar evoluindo sua espiritualidade? Porque conforme sua espiritualidade vai desenvolver seu corpo físico e sua mentalidade. Então isso aconteceu há muitos anos atrás. Só que os jurua são a maioria, e toda essa maioria foi afetada, sabe. Isso começou há muitos anos atrás, porque os Guarani sempre se mantiveram muito espirituais. A espiritualidade sempre em primeiro lugar.

B: Preocupados de que os filhos também tomassem esse caminho?

V: Sim, porque os jurua se tornaram muito materialistas. Isso foi mudando seu corpo, sua mentalidade, tudo isso. 
Se "não é descabido definir o discurso mítico como consistindo principalmente em um registro do processo de atualização do presente estado de coisas a partir de uma condição pré-cosmológica virtual dotada de perfeita transparência" (Viveiros de Castro, 2006, p. 323), então estamos frente a um pouco usual discurso mítico:

V: O ser humano é um dispositivo muito avançado. "A mais avançada da mais avançada das mais avançadas das tecnologias!" ${ }^{19}$ Ele fala né, que o índio descerá. Mas não é índio cara! Ele descreve um índio, por quê? Por que ele não descreveu um nhanderu mirî? Não era necessário ser um índio! Não sei cara, por quê? É que eu não consigo entender isso sabe, tipo, de existir indígenas e não indígenas. Os não indígenas são muito inteligentes também. A gente pode falar que os brancos são mais inteligentes, podemos dizer assim. Só que nós compreendemos que também não podemos dizer isso. Não temos necessidade de dizer isso. Porque para Nhanderu não somos nenhum inferior a outro. A diferença é só aqui no mundo sabe, só entre os humanos mesmo existe essa diferença. É que grandes filósofos se agruparam, né? Antigamente aconteceu isso - se agruparam e tentaram filosofar. Tipo, coletivamente. Aí ficaram cada vez mais agrupados e mais agrupados, e chegou nessa situação, sabe, da separação das raças. Era um grupo de filósofos, sabe, aí cada grupo virou um povo. Aí eles já preparavam os filhos para nascerem com tal filosofia. Todos eles com filosofias diferentes, todos esses grupos. Aí foram evoluindo nessas filosofias, evoluindo junto com sua espiritualidade, tendo essas filosofias, aí foram surgindo essas filosofias de vida muito diferentes.

B: Mas quem eram esses grupos de filósofos?

V: Isso é uma suposição minha.

B: Sim, mas tua suposição é que eles seriam filhos de Nhanderu? Eles viriam de onde? Nessa tua suposição, onde eles poderiam ter surgido?

V: Quando Nhanderu fez o primeiro ser humano.

B: Ele teria feito tipo uns grupos então?

V: Não, eles fizeram tipo um casal.

B: E como vieram os filósofos depois disso?

19 Referindo-se à canção de Caetano Veloso, “Um índio”. 
V: Cara, depois eles evoluíram e evoluíram e chegaram grandes filósofos. Evoluir é filosofar. A filosofia faz muito parte da evolução. A filosofia permite muita conexão com a espiritualidade. Tipo, foram evoluindo filosofando. É tipo ijapyxaka. Eu entendo essa coisa como isso.

$\mathrm{B}: \mathrm{Tu}$ acha que pode ter sido esse o surgimento de povos diferentes?

V: Sim, eu acho que é isso que vai definindo um grupo sabe. Como ele foi evoluindo de tal forma. Porque a nossa filosofia também influencia muito no nosso físico. Com toda nossa estrutura sabe?

B: Aí os grupos se espalharam pela terra?

V: Sim, se espalharam, foram surgindo gerações e gerações. Aí vão surgindo as gerações e a filosofia permanecia. Só que a própria filosofia evoluía, foram evoluindo e modificando. Conhecendo novas. É que todas essas coisas que estão acontecendo são por causa de nossa espiritualidade.

B: E tu acha que os corpos ficaram diferentes por quê? Nessa evolução da filosofia, o corpo também ficou diferente?

V: Porque daí foram surgindo as pessoas. Já foram surgindo culturas sabe, e aí já surgiram culturas, todas essas coisas que ajudaram a separar. Aí da filosofia nasceu cultura. Aí cada um com a sua cultura. Aí um dia vai chegar a cada um com sua raça. Agora chegou nisso.

B: Mas por que o corpo diferente?

V: É que aí os seres humanos foram se espalhando, formando cultura, foram se dividindo em koo yvy rupa [nesta terra]. Aí em cada lugar, climaticamente onde pertencia assim, conforme qual lugar eles viviam, o corpo foi evoluindo. Tipo o lugar do mais calor, mais quente, o corpo vai agir de outra forma lá. Aí eles começaram a achar a raça, começaram a surgir raças. Dentro da filosofia se formou a raça. Aí já é discutido raça sabe, "não, nós pertencemos a essa raça”, "essa é nossa cultura", "pertencemos a essa filosofia..."

B: E tu acha que antes de ser isso, eles eram um só?

V: Sim, eu acho que sim.

O que parece importante ser ressaltado é a noção de diferenças progressivas entre índios e brancos desde uma unicidade anterior, o Uno guarani que pode sempre guardar em si a saída para o Múltiplo - aquela virtualidade do duplo, sempre prestes a efetuar-se. Neste sentido, acaba por diferenciar-se de teorias de ruptura entre índios e brancos, colocando-os em diferença contínua, 
de acordo com Viveiros de Castro, em entrevista a Lagrou e Belaunde (2011, p. 18): "sempre uma pequena diferença que vai aumentando ou vai diminuindo, mas nunca acaba, é assintótica. Em suma, [...] não é uma oposição."

Os grupos de filósofos que foram diferenciando-se e espalhando-se através do globo estão intrinsecamente conectados com o tema da "má escolha" lévi-straussiano (Lévi-Strauss, 1993), já que uma das diferenças que foram sendo produzidas nessa separação progressiva entre índios e brancos é justamente a decisão dos brancos pelo "materialismo", algo que os deixa cada vez mais distantes dos deuses, e também da possibilidade de ascensão aos planos celestes pelo aguyje. Porém, ao contrário de diversas versões presentes entre os Mbya sobre a impossibilidade de os brancos alcançarem o aguyje, causada por sua "má escolha" (cf. Pierri, 2013), Vera'i, sem desconsiderar a dificuldade imposta por tal "apego material" dos jurua, defende a universalidade da possibilidade de maturação corporal (aguyje), aberta invariavelmente para quem dedicar-se a uma postura de escuta às ciências divinas (-japyxaka).

Ou seja, justamente por identificar que o mundo dos nhanderu é tão aberto ao passado quanto ao futuro, que Vera'i parece corroborar a perspectiva de que a natureza dos discursos míticos é sua capacidade de estarem constantemente atualizando um "fundo virtual indestrutível ou inesgotável" de onde o presente parece ser sempre uma imagem discreta (Viveiros de Castro, 2006, p. 324), sempre aberta ao evento - conforme vimos acima. Os mitos que Vera'i fez refratar através destas páginas, mostram que eles se prestam e são importantíssimos para pensar o presente (Calavia Sáez, 2002), na medida em que possibilitam, ao informar e serem informados, a maneira pela qual lida com as suas experiências e, especialmente, com os brancos.

\section{Considerações finais: do "criador de mundos" à jurualogia}

B: Tu acha que tem branco que virou nhanderu mirit?

V: Eu acho que sim. Eu acho que todos os seres humanos são muito espirituais.

No momento em que Vera'i compõe suas exegeses genesíacas, aproxima-se daquilo que Joanna Overing identificou enquanto as características próprias do xamanismo ameríndio, conforme discutimos anteriormente. 
Tais características seriam a de compor "versões de mundo" partindo dos "mundos a mão"; ou de seus quadros de referência (Overing, 1990, p. 605). Se entre as pessoas comuns os debates e as conversas são recorrentemente a respeito da ambiguidade dos seres do universo, o xamã seria aquele que sabe identificar se um morcego é um feiticeiro, ou se uma onça é a vingança de um deus (Overing, 1990, p. 610) - ele é a pessoa capaz de colocar alguma ordem em um mundo imanente.

Para isso, o xamã é aquele que articula histórias antigas (o "before talk" de Overing) com referências contemporâneas, ou aquele que cria "versões de mundos" nas quais as experiências atuais conseguem ser combinadas (Overing, 1990, p. 611). Ou seja, antes de estarmos diante de um mundo único e objetificável, os xamãs (amazônicos e, eu diria, guarani) nos mostram a possibilidade de fabricação de "versões de mundos" que fazem sentido à característica múltipla do cosmos e assim produzem a eficácia necessária aos seus objetivos. Dessa forma, parece-me que Vera'i usava os mundos que havia escutado e entendido/ observado, tanto de seus avós como de suas experiências próprias, para a composição de versões de universo em correspondência com suas experiências, com as minhas preocupações e com as características do universo celeste. Em certo sentido, Vera'i identificava a tradução que precisava produzir para outros "princípios metafísicos", processo semelhante às habilidades xamânicas piaroa, conforme apontadas por Overing (1990, p. 610).

Não obstante, assim como "dentro da nossa própria tradição filosófica, não existe uma metafísica única" (Overing, 1995, p. 122), dentro das tradições orais indígenas tampouco. Nesse sentido, Vera'i compunha múltiplos mundos, ou mundos não unos, muitas vezes conflitantes entre si desde um ponto de vista histórico, mas completamente coerentes com "princípios metafísicos básicos" nativos (Overing, 1995):

[...] não há por que supor que uma postura de pluralismo metafísico resulte em "bagunça relativista" ou "confusão filosófica" [...] Em primeiro lugar, a metafísica é um campo de natureza notadamente especulativa, quer "nas mãos" do filósofo ocidental, quer nas do cosmólogo indígena. (Overing, 1995, p. 121).

Dessa forma, se o obviado no pensamento ocidental são princípios de sequencialidade e lógica, a Vera'i, as qualidades morais e certos atributos deviam ser obviadas, às expensas de uma possível sequência temporal, na medida em que 
a maneira com que compunha suas explicações era extremamente coerente com as qualidades transtemporais e transespaciais dos nhanderu, já que eles são capazes de misturar tempos e espaços (Overing, 1990, p. 611) - fazendo, assim, que certas lógicas ocidentais se tornem impertinentes ao universo dos deuses e das histórias a eles correspondentes.

Era assim, justamente compondo tais versões de mundos complexas e criativas, que Vera'i cada vez mais se aproximava da figura de um xamã mbya (um karai) a seu modo. Durante esses meses de contato próximo, foi visível seu envolvimento crescente com técnicas de cura entre seus parentes, culminando com o tratamento realizado em outro karai na aldeia de Tamanduá, na Argentina, conforme vimos acima:

Tornei-me capaz de começar a apreciar a precisão de sua "fala antiga" ["before talk"] e de sua força organizadora na formulação de relações poderosas do universo. [...] E era o encapsulamento da história em sua poderosa "fala antiga" que dava às suas palavras a eficácia necessária no trabalho de proteção e de cura. (Overing, 1990, p. 616, tradução minha).

Na vizinhança de sua disposição mitopoiética, ou enquanto "criador de mundos" (Overing, 1990), revelava-se uma disposição xamânica, denunciada por seu avô desde seu batismo (nhemongarai) e que tangenciava suas práticas e experiências principalmente com os brancos. Já a jurualogia e suas justificativas lembram a capacidade salientada por Viveiros de Castro (2002, p. 358) a respeito dos xamãs ameríndios, em que: "Os xamãs são capazes de assumir o papel de interlocutores ativos no diálogo transespecífico [...] o encontro ou o intercâmbio de perspectivas é um processo perigoso, é uma arte política - uma diplomacia."

Dessa forma, Vera'i compunha, entre exegeses e experiências de contato, verdadeiras investigações a respeito dos brancos, típicas daqueles que se propõem ao diálogo interespécie conforme destacado acima. Nesse sentido, advogava com a jurualogia o método tornado característico dos xamãs ameríndios, onde "conhecer é personificar, tomar o ponto de vista daquilo que deve ser conhecido [...] A forma do Outro é a pessoa" (Viveiros de Castro, 2002, p. 358). Talvez por isso, enquanto outros Mbya temem o contato próximo com os jurua, Vera'i os vê enquanto parte de um fundo humano virtual e reflexivo, e seu contato enquanto imprescindível para aqueles que buscam o conhecimento 
verdadeiro dos nhanderu. De toda forma, Vera'i passou a ser chamado por seus familiares para aplicar-lhes a fumaça do petyngua (cachimbo), terapia usual dos karai para a cura de enfermidades.

Como Vera'i mesmo falava, suas descrições cosmogônicas são sempre suposições e imaginações dele próprio em seus processos meditativos e de inspiração divina, na medida em que tenta entender o universo tal qual uma formiguinha que tem pouco acesso à verdade, mas que sente os restos das ações de seres elevados e superiores. Dessa maneira, portanto, sua capacidade de "criador de mundos" quando conjecturava sobre a origem dos povos e da humanidade, somada à sua busca pelo ponto de vista jurua através da jurualogia, fazia com que Vera'i se aproximasse cada vez mais das previsões de seus familiares a respeito de sua vocação xamânica.

\section{Referências}

CADOGAN, L. Ayvu Rapyta: textos míticos de los Mbyá-Guarani del Guairá. Asunción: Fundación León Cadogan, 1992. (Biblioteca Paraguaya de Antropologia, 16).

CALAVIA SÁEZ, O. A variação mítica como reflexão. Revista de Antropologia, São Paulo, v. 45, n. 1, p. 7-36, 2002.

CALAVIA SÁEZ, O. A história pictográfica. In: QUEIROZ, R. C. de; NOBRE, R. F. (Org.). Lévi-Strauss: leituras brasileiras. Belo Horizonte: Editora UFMG, 2008. p. 125-146.

DOOLEY, R. A. Léxico guarani, dialeto mbyá: versão para fins acadêmicos. Porto Velho: Sociedade Internacional de Linguística, 1998.

GOW, P. An Amazonian myth and its history. New York: Oxford University Press, 2001.

HEURICH, G. O. Outras alegrias: parentesco e festas mbya. 2011. Dissertação (Mestrado em Antropologia Social)-Museu Nacional, Universidade Federal do Rio de Janeiro, Rio de Janeiro, 2011.

HUYER, B. Do efeito dos outros: crônicas sobre a mistura entre os Guarani-Mbya. 2017. Dissertação (Mestrado em Antropologia Social)-Centro de Filosofia e Ciências Humanas, Universidade Federal de Santa Catarina, Florianópolis, 2017.

LAGROU, E.; BELAUNDE, E. Do mito grego ao mito ameríndio: uma entrevista sobre Lévi-Strauss com Eduardo Viveiros de Castro. Sociologia e Antropologia, Rio de Janeiro, v. 1, n. 2, p. 9-33, 2011. 
LÉVI-STRAUSS, C. História de lince. São Paulo: Companhia das Letras, 1993.

MACEDO, V.; SZTUTMAN, R. A parte de que se é parte: notas sobre individuação e divinização (a partir dos Guarani). Cadernos de Campo, São Paulo, v. 23, n. 23, p. 287302, 2014.

NIETZSCHE, F. Além do bem e do mal: prelúdio a uma filosofia do futuro. São Paulo: Companhia das Letras, 2005.

NIMUENDAJÚ, C. As lendas da criação e destruição do mundo como fundamentos da religião dos Apapocúva-Guarani. São Paulo: Hucitec: Edusp, 1987.

OVERING, J. The shaman as a maker of worlds: Nelson Goodman in the Amazon. Man, London, v. 25, n. 4, p. 602-619, 1990.

OVERING. J. O mito como história: um problema de tempo, realidade e outras questões. Mana, Rio de Janeiro, v. 1, n. 1, p. 107-140, 1995.

PIERRI, D. C. O perecível e o imperecível: lógica do sensível e corporalidade no pensamento guarani-mbya. 2013. Dissertação (Mestrado em Antropologia Social)-Faculdade de Filosofia, Letras e Ciências Humanas, Universidade de São Paulo, São Paulo, 2013.

SOARES, M. Caminhos para viver o mbya reko. 2012. Tese (Doutorado em Antropologia Social)-Instituto de Filosofia e Ciências Humanas, Universidade Federal do Rio Grande do Sul, Porto Alegre, 2012.

TARDE, G. Monadologia e sociologia: e outros ensaios. São Paulo: Cosac Naify, 2007.

VIVEIROS DE CASTRO, E. A inconstância da alma selvagem: e outros ensaios de antropologia. São Paulo: Cosac Naify, 2002.

VIVEIROS DE CASTRO, E. Perspectival anthropology and the method of controlled equivocation. Tipití, San Antonio, v. 2, n. 1, p. 3-22, 2004.

VIVEIROS DE CASTRO, E. A floresta de cristal: notas sobre a ontologia dos espíritos amazônicos. Cadernos de Campo, São Paulo, v. 15, n. 14/15, p. 318-338, 2006.

WAGNER, R. A invenção da cultura. São Paulo: Cosac Naify, 2010.

Recebido: 30/05/2017 Aceito: 14/03/2018 | Received:5/30/2017 Accepted: 3/14/2018 